\title{
A method of determining daily nitrogen requirements
}

\author{
H. A. LEE \\ B.SC., M.B., B.S., F.R.C.P. \\ T. F. HARTLEy \\ B.Sc., Ph.D.

\begin{abstract}
Department of Nephrology, University of Southampton, St Mary's General Hospital, Portsmouth, Hants
\end{abstract}

\begin{abstract}
Summary
A simple formula for calculating daily nitrogen requirements and balance is presented. A close correlation was observed between calculated and actual nitrogen balance studies. For better precision a different correction factor is suggested for patients receiving protein hydrolysates and crystalline amino acid solutions. This formula will greatly aid those who have to devise complete intravenous nutrition regimes for patients whose condition varies daily. The biochemistry required for application of this formula is within the capacity of any small hospital laboratory.
\end{abstract}

WrTH the increasing awareness of the value of parenteral nutrition using nitrogen and energy source solutions in the management of acute metabolic illness (Allen and Lee, 1969; Lee, 1974a; Editorial, Lancet, 1973) there is a need to have a method of assessing daily nitrogen requirements in such patients. Successful intravenous therapy requires a daily reassessment of the patient's nitrogen losses and hence there is a need for a simple method of determining nitrogen requirements without the provision of extra laboratory facilities. It is necessary to determine daily nitrogen losses because these deficits may be considerably larger than anticipated and are further influenced by concurrent problems such as sepsis and wound complications. Many other factors in the design of an intravenous nutritional regime depend upon a knowledge of nitrogen requirements (Lee, 1974b); thus for optimum nitrogen utilization there is (i) a minimum calorie/nitrogen ratio of $200: 1$, (ii) a minimum potassium requirement of 5-6 mEq/g of nitrogen and (iii) a probable magnesium requirement of $2 \mathrm{mEq} / \mathrm{g}$ of nitrogen.

If a simple method could be devised that gave an estimate within $10 \%$ of the actual nitrogen requirements, this would be an extremely useful clinical measurement. It would also follow that intravenous feeding regimes could be practised with greater confidence on the basis of measurement rather than empiricism or rough guesses which often under- estimate the true needs. Furthermore, the high cost of intravenous nutrition makes it that more important to improve upon the cost-effectiveness by determining exactly what is required rather than use a 'recipe' approach with the risk of giving excessive amounts of other unnecessary nutrients. Any method of clinical nitrogen balance must also hold good irrespective of the nitrogen source solutions used, namely, pure crystalline amino acid solutions or protein hydrolysates.

Lee (1969) proposed a formula for clinical nitrogen balance that depended principally on the measurement of 24-hr urinary urea nitrogen excretion and equating this to $80 \%$ of the total urinary nitrogen excretion. The remaining $20 \%$ was assumed to consist of ammonia, purines, creatinine, alpha amino nitrogen and other unidentified nitrogen. Rarely, there is a correction to be made should any significant proteinuria be present.

\section{Method}

Eleven patients all with normal renal function who had been treated by elective vagotomy and pyloroplasty were studied over a 6-day post-operative period when they received complete intravenous nutrition only. Complete nitrogen balance studies were undertaken inclusive of measuring faecal and nasogastric aspirate nitrogen. All patients received iso-caloric and iso-nitrogenous regimes and the calories were derived from identical sources (Hartley and Lee, 1975). Six patients received a crystalline L-amino acid preparation, Vamin, which contains all the essential amino acids and a balanced nonessential amino acid content. The other five patients received a casein hydrolysate, Aminosol $10 \%$, which also contains all the essential amino acids, but in addition to non-essential amino acids contains an appreciable proportion of small molecular weight peptides and some ammonia.

The urinary nitrogen constituents measured were: total nitrogen (Micro-Kjeldahl method), ammonia, urea, creatinine and, by subtraction from the total nitrogen, unidentified nitrogen. 
TABLE 1. Nitrogen excretion data obtained during the parenteral nutrition investigations

\begin{tabular}{|c|c|c|c|c|c|c|c|c|}
\hline \multirow[b]{2}{*}{$\begin{array}{l}\text { Post- } \\
\text { operative } \\
\text { day }\end{array}$} & \multicolumn{4}{|c|}{ Vamin } & \multicolumn{4}{|c|}{ Aminosol } \\
\hline & $\begin{array}{l}\mathbf{g ~ N} \text { in } \\
\text { urine as } \\
\text { urea }\end{array}$ & $\begin{array}{c}\text { Serum } \\
\text { urea } \\
\mathrm{mg} / 100 \mathrm{ml}\end{array}$ & $\begin{array}{c}\text { Calculated } \\
\text { total g N } \\
\text { excreted }\end{array}$ & $\begin{array}{l}\text { Observed } \\
\text { total } \mathbf{g ~ N} \\
\text { in urine }\end{array}$ & $\begin{array}{l}\mathbf{g ~ N} \text { in } \\
\text { urine as } \\
\text { urea }\end{array}$ & $\begin{array}{c}\text { Serum } \\
\text { urea } \\
\mathrm{mg} / 100 \mathrm{ml}\end{array}$ & $\begin{array}{c}\text { Calculated } \\
\text { total g N } \\
\text { excreted }\end{array}$ & $\begin{array}{c}\text { Observed } \\
\text { total } \mathrm{g} \mathrm{N} \\
\text { in urine }\end{array}$ \\
\hline & \multicolumn{4}{|c|}{ Patient G.W. $(81 \cdot 1 \mathrm{~kg})$} & \multicolumn{4}{|c|}{ Patient A.B. $(68.5 \mathrm{~kg})$} \\
\hline 1 & $10 \cdot 90$ & $42 \cdot 5$ & $15 \cdot 84$ & $14 \cdot 08$ & $17 \cdot 67$ & - & $21 \cdot 20$ & $22 \cdot 78$ \\
\hline 2 & $14 \cdot 50$ & - & $19 \cdot 21$ & $17 \cdot 07$ & $13 \cdot 89$ & - & $16 \cdot 67$ & $20 \cdot 80$ \\
\hline 3 & $15 \cdot 25$ & $34 \cdot 0$ & $19 \cdot 00$ & $19 \cdot 26$ & $13 \cdot 84$ & - & $16 \cdot 60$ & $21 \cdot 07$ \\
\hline 4 & $11 \cdot 68$ & - & $14 \cdot 66$ & $15 \cdot 23$ & $13 \cdot 50$ & - & $16 \cdot 20$ & $19 \cdot 00$ \\
\hline 5 & - & $32 \cdot 0$ & - & - & $11 \cdot 99$ & - & $14 \cdot 39$ & $16 \cdot 06$ \\
\hline 6 & - & $43 \cdot 0$ & - & - & $7 \cdot 76$ & $32 \cdot 0$ & $9 \cdot 31$ & $11 \cdot 88$ \\
\hline & \multicolumn{4}{|c|}{ Patient L.W. $(54.0 \mathrm{~kg})$} & \multicolumn{3}{|c|}{ Patient F.B. $(83.4$ kg) } & \\
\hline 1 & $10 \cdot 75$ & $32 \cdot 8$ & $13 \cdot 10$ & $12 \cdot 58$ & $11 \cdot 46$ & $13 \cdot 6$ & $13 \cdot 75$ & $18 \cdot 12$ \\
\hline 2 & $11 \cdot 97$ & - & $14 \cdot 36$ & $14 \cdot 22$ & $12 \cdot 55$ & $19 \cdot 5$ & $15 \cdot 06$ & $20 \cdot 83$ \\
\hline 3 & $9 \cdot 79$ & $28 \cdot 5$ & 11.95 & $11 \cdot 97$ & $13 \cdot 45$ & - & $16 \cdot 14$ & $21 \cdot 40$ \\
\hline 4 & $10 \cdot 24$ & - & $12 \cdot 29$ & $12 \cdot 51$ & $14 \cdot 10$ & - & $16 \cdot 92$ & $20 \cdot 21$ \\
\hline 5 & $11 \cdot 22$ & $32 \cdot 8$ & $13 \cdot 66$ & $12 \cdot 18$ & $13 \cdot 41$ & - & $16 \cdot 09$ & $19 \cdot 73$ \\
\hline 6 & $9 \cdot 77$ & $28 \cdot 5$ & $11 \cdot 72$ & $12 \cdot 15$ & $12 \cdot 29$ & - & $14 \cdot 75$ & $18 \cdot 80$ \\
\hline & \multicolumn{4}{|c|}{ Patient W.W. $(84 \cdot 3 \mathrm{~kg})$} & \multicolumn{3}{|c|}{ Patient J.B. (66.2 kg) } & \\
\hline 1 & $15 \cdot 26$ & - & $23 \cdot 03$ & $19 \cdot 04$ & $9 \cdot 24$ & - & $11 \cdot 09$ & $13 \cdot 11$ \\
\hline 2 & $18 \cdot 99$ & $74 \cdot 0$ & $32 \cdot 23$ & $22 \cdot 56$ & $18 \cdot 07$ & - & $21 \cdot 68$ & $27 \cdot 30$ \\
\hline 3 & $17 \cdot 40$ & - & $27 \cdot 27$ & $18 \cdot 85$ & $8 \cdot 66$ & - & $10 \cdot 39$ & $14 \cdot 23$ \\
\hline 4 & $16 \cdot 21$ & $45 \cdot 5$ & $22 \cdot 28$ & 16.99 & $9 \cdot 52$ & - & $11 \cdot 42$ & $19 \cdot 55$ \\
\hline 5 & $10 \cdot 63$ & - & $14 \cdot 40$ & $14 \cdot 78$ & $12 \cdot 31$ & - & $14 \cdot 77$ & $18 \cdot 32$ \\
\hline 6 & $7 \cdot 69$ & $36 \cdot 5$ & $9 \cdot 31$ & $10 \cdot 02$ & $8 \cdot 92$ & - & $10 \cdot 70$ & $16 \cdot 93$ \\
\hline & \multicolumn{4}{|c|}{ Patient K.S. $(58.9$ kg) } & \multicolumn{3}{|c|}{ Patient F.S. $(82 \cdot 3 \mathrm{~kg})$} & \\
\hline 1 & - & - & - & - & $12 \cdot 60$ & - & $15 \cdot 10$ & $17 \cdot 44$ \\
\hline 2 & $15 \cdot 72$ & - & $19 \cdot 56$ & $19 \cdot 68$ & $12 \cdot 83$ & - & $15 \cdot 39$ & $20 \cdot 46$ \\
\hline 3 & $17 \cdot 11$ & $39 \cdot 0$ & $21 \cdot 35$ & $21 \cdot 14$ & $14 \cdot 08$ & - & $16 \cdot 89$ & $21 \cdot 59$ \\
\hline 4 & $15 \cdot 90$ & 一 & $19 \cdot 27$ & $19 \cdot 26$ & $15 \cdot 15$ & - & $18 \cdot 18$ & $23 \cdot 95$ \\
\hline 5 & $16 \cdot 64$ & $32 \cdot 0$ & $19 \cdot 97$ & $18 \cdot 65$ & $11 \cdot 26$ & - & $13 \cdot 51$ & $18 \cdot 68$ \\
\hline 6 & $12 \cdot 51$ & - & $15 \cdot 01$ & $15 \cdot 72$ & $12 \cdot 00$ & - & $14 \cdot 40$ & $19 \cdot 89$ \\
\hline & \multicolumn{4}{|c|}{ Patient G.B. $(102 \cdot 7 \mathrm{~kg})$} & \multicolumn{3}{|c|}{ Patient T.S. $(55.0 \mathrm{~kg})$} & \\
\hline 1 & $14 \cdot 62$ & - & $17 \cdot 63$ & $19 \cdot 65$ & $10 \cdot 79$ & - & $12 \cdot 95$ & $17 \cdot 77$ \\
\hline 2 & $13 \cdot 81$ & - & $16 \cdot 74$ & $18 \cdot 04$ & $7 \cdot 94$ & $31 \cdot 0$ & $9 \cdot 53$ & $14 \cdot 78$ \\
\hline 3 & $13 \cdot 37$ & $34 \cdot 0$ & $16 \cdot 33$ & $21 \cdot 99$ & $9 \cdot 97$ & - & $11 \cdot 96$ & $17 \cdot 00$ \\
\hline 4 & $15 \cdot 76$ & - & $19 \cdot 08$ & $20 \cdot 51$ & $7 \cdot 25$ & - & $8 \cdot 70$ & $16 \cdot 38$ \\
\hline 5 & $14 \cdot 85$ & $28 \cdot 0$ & $17 \cdot 93$ & 20.97 & $9 \cdot 56$ & - & $11 \cdot 47$ & $15 \cdot 59$ \\
\hline 6 & $13 \cdot 49$ & $27 \cdot 0$ & $16 \cdot 28$ & $17 \cdot 45$ & $7 \cdot 54$ & $一$ & $9 \cdot 05$ & $13 \cdot 00$ \\
\hline & \multicolumn{4}{|c|}{ Patient E.R. $(74.8 \mathrm{~kg})$} & & & & \\
\hline 1 & $11 \cdot 72$ & - & $14 \cdot 10$ & $15 \cdot 71$ & & & & \\
\hline 2 & $11 \cdot 59$ & $30 \cdot 8$ & $14 \cdot 99$ & $15 \cdot 58$ & & & & \\
\hline 3 & $10 \cdot 36$ & - & $12 \cdot 43$ & $14 \cdot 23$ & & & & \\
\hline 4 & $10 \cdot 87$ & - & $13 \cdot 04$ & $14 \cdot 31$ & & & & \\
\hline 5 & $11 \cdot 06$ & 27 & $13 \cdot 27$ & $14 \cdot 93$ & & & & \\
\hline 6 & $10 \cdot 96$ & $31 \cdot 5$ & $13 \cdot 24$ & $14 \cdot 72$ & & & & \\
\hline
\end{tabular}

\section{Results}

Table 1 shows the total daily urinary nitrogen excretion, body weight and blood urea concentrations measured during the 6-day observation period and the corresponding total nitrogen excretion as calculated from the Lee formula. This formula is derived as follows:

(i) 24-hr urine urea in $\mathrm{g} \times \frac{28}{60} \times \frac{6}{5}=\mathrm{X} \times 0.56=$ (a) $\mathrm{g}$

(ii) Measure proteinuria, if any,

$$
\text { i.e. } Y \times \frac{4}{25}=Y \times 0 \cdot 16=
$$

(iii) Correction for blood urea (B.U.) change Body water $=60 \%$ body wt in $\mathrm{kg}$

Rise in B.U. $=\mathrm{Y} \mathrm{mg} \%=\mathrm{Z} \mathrm{g} / \mathrm{l}$

$$
\begin{aligned}
Z & \times 60 \% \text { body wt } \times \frac{28}{60} \\
=Z & \times \text { body wt } \times 0.28=
\end{aligned}
$$

(a) + (b) $+($ c $)=$ nitrogen loss

To convert nitrogen loss to protein catabolism multiply by $6 \cdot 25$.

The results for faecal nitrogen excretion showed these losses to be small in comparison to the urinary 
nitrogen losses of 10-24 g/day. They accounted for no more than $2-5 \%$ of the total daily nitrogen excretion. Correction of the daily nitrogen requirements for such small losses would not add significantly to nitrogen balance maintenance.

The correlations between calculated and observed nitrogen balance for Vamin and Aminosol solutions respectively are shown in Figs 1 and 2. Correlation coefficients of 0.784 and 0.89 were obtained for the Vamin- and Aminosol-treated groups of patients respectively which were significant at $\boldsymbol{P}<0.001$ level. The slope of the line in Fig. 1 indicated that this method overestimated the nitrogen losses by less than $13 \%$ or $2 \mathrm{~g}$ of nitrogen daily. In contrast the slope of the line in Fig. 2 showed that this approximation underestimated the daily total nitrogen losses by $12 \%$ or approximately $2 \mathrm{~g} /$ day. The regression equation for the data shown in Fig. 1 demonstrated that when the observed urinary nitrogen excretion was between 10 and $25 \mathrm{~g} /$ day then the formula predicted these amounts to within $-6 \%$ and $+5.2 \%$ of the correct amounts respectively, i.e. equivalent to $-0.6+1 \cdot 2 \mathrm{~g}$ of nitrogen/day. The data obtained from patients receiving the $10 \%$ Aminosol infusions, however, did not show such a close relationship. Over the same range of observed urinary nitrogen excretion the agreement was in the range of $-33 \%$ to $-21.2 \%$ of

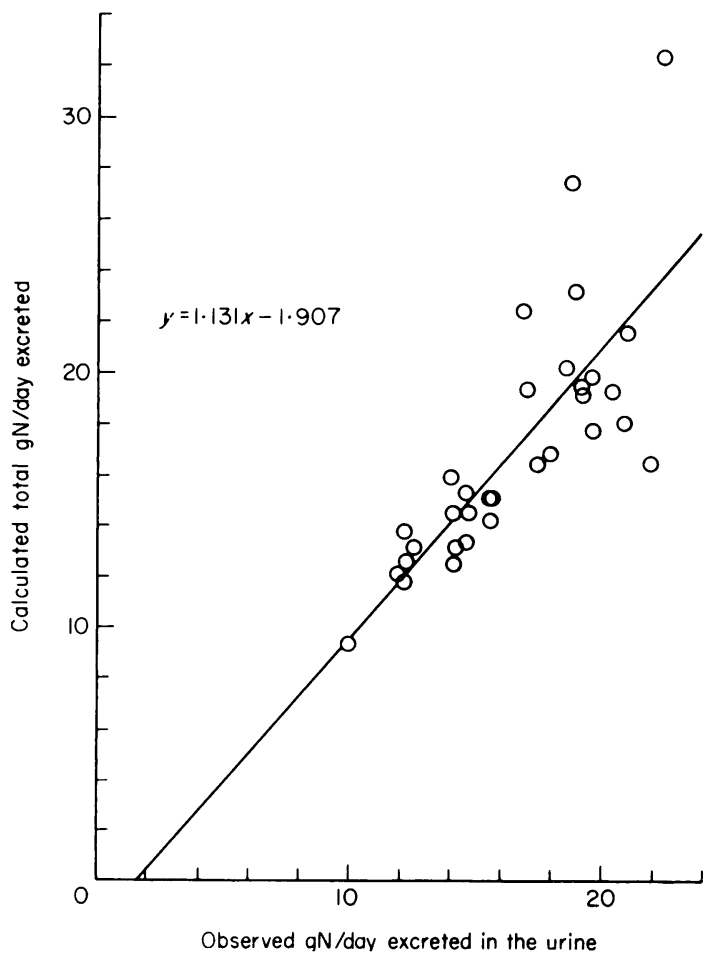

Fig. 1. Correlation between observed and calculated nitrogen excretion in 'Vamin'-treated patients.

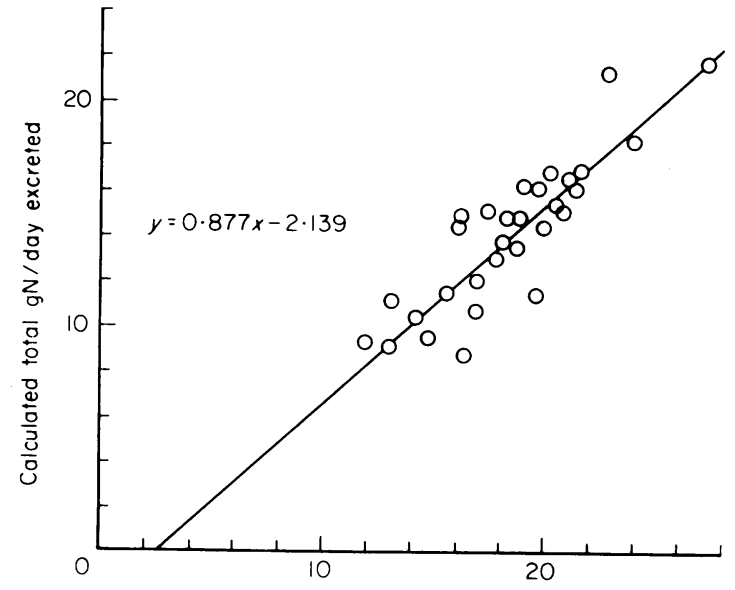

Observed gN/day excreted in the urine

Fig. 2. Correlation between observed and calculated nitrogen excretion in 'Aminosol'-treated patients.

the correct amount, i.e. the formula consistently underestimated the observed nitrogen excretion by between 3.4 and $5.1 \mathrm{~g}$ of nitrogen/day. The difference arising from the application of this formula to the two solutions was traced to the differences in the regression equations calculated for the graphs of the observed total nitrogen excreted in the urine $\mathrm{N}_{\text {obs }} v s$ the $g$ of nitrogen in the urine excreted as urea $(Y)$. Thus, from the data for the Vamin infusions $\mathrm{Y}_{\mathrm{Vamin}}=$ $0.7435 \mathrm{~N}_{\text {obs }}+0.8071$ (correlation coefficient $=0.893$ ). Similarly, the data for Aminosol infusions show $Y_{\text {Aminosol }}=0.7314 \mathrm{~N}_{\text {obs }}$ equal to $10 \mathrm{~g}$, and $24 \mathrm{~g}$ of nitrogen into these equations show the corresponding values of $Y_{\text {Vamin }}$ were equal to $82.4 \%$ and $77.6 \%$ of $\mathrm{N}_{\text {obs }}$, whereas those for $\mathrm{Y}_{\text {Aminosol }}$ were only $55.3 \%$ and $66.0 \%$ of $\mathrm{N}_{\text {obs. }}$. This reduced proportion of the total urinary nitrogen appearing as urea during the $10 \%$ Aminosol infusion was responsible for the poor prediction of the total daily nitrogen excretion using this formula. These observations have been further supported by studies on six other patients undergoing identical treatment protocols but who received their nitrogen from a new crystalline amino acid preparation $\left(\mathrm{C}_{2} \mathrm{E}\right.$ supplied by Pharmacia) (Table 2$)$.

It is apparent therefore that the current Lee formula is acceptable using the figure $6 / 5$, i.e. a $20 \%$ allowance for non-urea nitrogen is accurate for non-treated patients and those receiving crystalline amino acid proparations such as Vamin or $\mathrm{C}_{2} \mathrm{E}$. However, for those patients treated with casein hydrolysates such as $10 \%$ Aminosol a $4 / 3$ correction, i.e. Xg urea $\times 0.62$ should be substituted for $6 / 5$. These latter observations would appear to be in agreement with those earlier workers (Christensen et al., 1954; Christensen et al., 1955; Brocard, Akoun and Fabiani, 1964; Peaston, 1966; Heller, 1972) who 
TABle 2. Proportion of total urine nitrogen $X$ appearing as urea nitrogen $Y$, calculated from appropriate regression equations derived for the three treatment groups

\begin{tabular}{|c|c|c|c|c|c|c|}
\hline \multirow[b]{2}{*}{$\begin{array}{l}\mathbf{X} \\
(\mathbf{Y} / \mathrm{X}) \% \text { urea }\end{array}$} & \multicolumn{2}{|c|}{ Vamin } & \multicolumn{2}{|c|}{ Aminosol } & \multicolumn{2}{|c|}{$\mathrm{C}_{2} \mathrm{E}$} \\
\hline & $\begin{array}{c}10 \\
82 \cdot 4\end{array}$ & $\begin{array}{c}25 \\
77 \cdot 6\end{array}$ & $\begin{array}{c}10 \\
55 \cdot 3\end{array}$ & $\begin{array}{c}25 \\
66 \cdot 0\end{array}$ & $\begin{array}{c}10 \\
81 \cdot 7\end{array}$ & $\begin{array}{c}25 \\
75 \cdot 8\end{array}$ \\
\hline
\end{tabular}

found an approximate $15 \%$ urinary loss of parenterally administered casein hydrolysates.

\section{Discussion}

Our studies indicated that a simple clinical method of determining nitrogen excretion is available for calculating daily nitrogen requirements which closely approximates to actual measured data to within less than plus or minus $2 \mathrm{~g}$ of nitrogen/day. Furthermore, since the precise nitrogen intake is readily determined in patients having complete parenteral nutrition, the method allows calculation of daily nitrogen balance in most cases. Over the 6-day period for which measurements were made it was found that the proportion of urinary urea nitrogen to the total excreted remains the same. The amended formula is easy to apply, requiring only straightforward 24-hr urine collections and routine blood samples for analysis.

There is little reason to believe that different synthetic crystalline amino acid solutions will require separate modifications to the formula. A new experimental crystalline amino acid solution with a substantially different formula $\left(C_{2} E\right.$ Pharmacia) and $\mathrm{E} / \mathrm{T}$ ratio was shown to have a similar nitrogen excretion pattern to Vamin (Hartley and Lee, 1974). Since all nitrogen source solutions in the United Kingdom are derived from either protein hydrolysates or synthetic preparations, the formula will meet all clinical requirements concerning parenteral nutrition. However, it should be stressed that no conclusions should be drawn from the urinary nitrogen excretion profiles as to the availability and efficiency of the infused nitrogen for protein synthesis. The infusion of isonitrogenous amounts of protein hydrolysates and synthetic preparations has been shown to have an equal effect on nitrogen balance (Tweedle, 1973; Tweedle, Spivey and Johnston, 1973; Lee and Hartley, 1974).

This formula will be valuable for most patients receiving complete intravenous nutrition regimes though there are a few limitations to its application. This formula can probably be equally applied to intravenous nutrition regimes in premature and neonatal babies with their marked anabolic tendency and varying element retention ratios. It must also be appreciated that in adult conditions where large extra-renal protein losses occur, e.g. fulminating ulcerative colitis and fistulae, this formula will underestimate daily nitrogen requirements. In patients with renal failure undergoing dialysis treatment either peritoneal or haemodialysis this formula will not be applicable. In the non-dialysed acute renal failure patients the formula is applicable though the corrections for blood urea change will assume greater importance.

It should be stressed that the blood urea correction should only be applied where a positive correction is being made to the net total nitrogen output, i.e. when a blood urea rise occurs. No negative correction should ever be applied. The blood urea correction is also dependent upon the constancy of a patient's fluid balance and any large deficits have usually been corrected very early in a patient's illness. Very large aberrations in fluid balance have to occur before significantly altering the value of this formula.

\section{Acknowledgments}

We wish to thank Mr W. G. Prout, Consultant Surgeon, for his co-operation with these studies carried out on his patients. Our thanks are also due to Vitrum, Stockholm, and Pharmacia, Uppsala, for some financial support for this research work.

\section{References}

Allen, P.C. \& Lee, H.A. (1969) A Clinical Guide to Intravenous Nutrition. Blackwell Scientific Publications, Oxford.

Brocard, H., Akoun, G. \& Fabiani, P. (1964) Parenteral feeding in chest disease. In: 1st World Fat Congress, Hamburg, p. 1.

Christensen, H.N., Wilber, P.B., Coyne, B.A. \& Fisher, J.H. (1954) Comparative effects of fructose and glucose in the fate of infused amino acids and peptides. Journal of Clinical Investigations, 33, 923.

Christensen, H.N., Wilber, P.B., Coyne, B.A. \& Fisher, J.H. (1955) Effects of simultaneous or prior infusion of sugars on the fate of infused protein hydrolysates. Journal of Clinical Investigations, 34, 86.

EDITORIAL (1973) Lancet, ii, 1179.

Hartley, T.F. \& LEe, H.A. (1975) Investigations into the optimum nitrogen and caloric requirements and comparative nutritive value of three intravenous amino acid solutions in the postoperative period (in press).

Heller, L. (1972) Problems of parenteral nutrition in pregnancy. In: Parenteral Nutrition (Ed. A. W. Wilkinson), p. 180. Churchill Livingstone, Edinburgh and London.

LEE, H.A. (1969) Design of an intravenous diet and some practical observations. In: A Clinical Guide to Intravenous Nutrition (Ed. by P. C. Allen and H. A. Lee), p. 144. Blackwell Scientific Publications, Oxford.

LEE, H.A. (1974a) Parenteral Nutrition in Acute Metabolic Illness. Academic Press, London.

LEE, H.A. (1974b) Intravenous nutrition. British Journal of Hospital Medicine, 2, 719.

LEE, H.A. \& HARTLEY, T.F. (1974) Comparison of a Casein Hydrolysate with crystalline amino acid solutions during Intravenous Nutrition in the post-operative period. 
Scientific Abst. 1st World Congress on Intensive Care, London, p. 92.

Peaston, M.J.T. (1966) Design of an intravenous diet of amino acids and fat suitable for intensive patient care. British Medical Journal, ii, 388.

TweEDLE, D.E.F. (1973) The effects of amino acid solutions of differing composition on the nitrogen balance of postoperative patients. Journal of the Royal College of Surgeons (Edinburgh), 18, 280.

Tweedle, D.E.F., SpIvey, J. \& Johnston, I.D.A. (1973) Choice of intravenous amino acid solutions for use after surgical operation. Metabolism, 22, 173. 